\title{
Carbon Fiber Reinforced Polymers Used for Strengthening of Existing Reinforced Concrete Structures
}

\author{
SORIN DAN ${ }^{1 *}$, CORNELIU BOB ${ }^{1}$, CATALIN BADEA ${ }^{1}$, DANIEL DAN ${ }^{1}$, CONSTANTIN FLORESCU ${ }^{2}$, LILIANA COTOARBA ${ }^{2}$, \\ VASILE PODE ${ }^{3}$, AURELIAN GRUIN ${ }^{4}$ \\ 1 Politehnica University Timisoara, Department of Civil Engineering and Building Services Engineering, 2 Traian Lalescu Str., \\ 300223, Timisoara, Romania \\ 2 Politehnica University Timisoara, Department of Hydrotechnical Engineering, 1A George Enescu Str., 300022, Timisoara, \\ Romania \\ ${ }^{3}$ Politehnica University Timisoara, Department of Applied Chemistry and Engineering of Organic and Natural Compounds, \\ 6 Carol Telbisz Str., 300001, Timisoara, Romania \\ ${ }^{4}$ NIRD URBAN-INCERC. 2 Traian Lalescu Str., 300223, Timisoara, Romania
}

\begin{abstract}
The paper deals with some aspects regarding the behavior of modern and efficient solutions - for rehabilitation of reinforced concrete framed structures. The paper is devoted to experimental studies on carbon fiber reinforced polymer (CFRP) systems used as strengthening solution for reinforced concrete (RC) frames assumed as existing structures, which were tested as un-strengthened and as (CFRP) strengthened structures. Single span and single story frames (scale 1:2) were designed and detailed according to the Romanian design codes from 1970s under which seismic design was inadequate. The $R C$ design and the magnitude of applied forces were ensuring the failure mechanism, of non-strengthened $R C$ frames, by plastic hinges at columns ends. Then the columns were strengthened by using CFRP materials. The experimental program emphasized some importantaspects regarding the behavior and failure by debonding of CFRP strengthening materials applied to $R C$ frames. The analysis of experimental data and theoretical values showed up an increase of resistance and stiffness achieved by strengthening.
\end{abstract}

Keywords: carbon fiber reinforced polymer, existing reinforced concrete structures, strengthening, behavior and failure of carbon fiber reinforced polymer strengthening system

Reinforced concrete $(\mathrm{RC})$ structures are to be repaired and/or strengthened in cases when the general damage is limited, and demolished when the structural safety is greatly affected and the rehabilitation cost is very high.

Repairs are used for surface deterioration, cracks, casting defects and reinforcement corrosion. By repairing there is no increase in strength or stiffness in relation to the initial structure. The methods used for repairs are: covering of damaged surfaces; infilling of cracks with cement mortar, epoxy resin or other polymers; replacement or strengthening of damaged reinforcement.

Strengthening of reinforced concrete structures may take into account the increase of strength and/or stiffness and/or ductility. In case of RC framed structures, the increase in stiffness and ductility is possible to be achieved by jacketing beams, columns and joints [1]. The jacketing is performed by reinforced concrete, steel profiles, carbon fibers.

Sometimes it is necessary to transform the existing structure completely, especially for framed structures. In this case, special techniques are to be used: steel bracing; infilling of frame openings with reinforced masonry or reinforced concrete.

CFRP systems are suitable for strengthening of RC structures due to their technical and economical advantages. Classic strengthening solutions may lead to some inconveniences, since these methods have been costly and disruptive to operation. A typical approach is the increasing of elements' dimensions with consequentmass increasing and leading to seismic problems. Furthermore, if reinforcement corrosion is presentand its causes are not carefully removed the corrosion will continue.

CFRP systems' advantages as rehabilitation application at seismic resistant structures are: increase of loadcarrying capacity; structural elements designed only for gravity loads will be able to withstand seismic loads; elements' mass remains, practically, the same; the technology is simple and rapid [2] .

For strengthening of existing RC framed structures in seismic zones a very important target is to avoid the development of plastic hinges in columns. Results the necessity to increase columns' bending and shear resistance. A retrofit using CFRP vertical strips and horizontal wrap for columns means increasing of local ductility and deformation capacity as well as of entire bending capacity.

The strengthening of columns using CFRP vertical strips will increase the resistance capacity as well as the stiffness of the element. The increased flexural strength of column will force the plastic hinge to form at beam ends. On the other hand the increase of vertical elements stiffness will reduce the structural story drift under seismic motion.

The two effects of columns strengthening are responsible for increasing the horizontal load capacity and, finally, the structural dissipation energy. The advantages presented above are effective only if the shear capacity is also increasing and the debonding of vertical CFRP strips is eliminated by efficient systems.

The possibility of avoiding shear failure of column end (potential plastic hinge) may be solved by CFRP wrap 
confinement; results and increase of column shear strength, as well as ductility, and will transmit the plastic hinge at the beams.

The debonding of FRP strips, disposed along the column axis, in the form of peeling-off failure at the beam-column joint or column-foundation joint, it is necessary to be solved by different systems: a continuous fiber application in the longitudinal column direction where this possibility exists; by creating of some vertical gaps around the columns in which strips are anchored; by using special anchoring devices, such as steel plates and rods (El-Amoury and Ghobarah [3], Parese et al [4]). The verifying of the end anchorage can follows the model presented in the fib bulletin 14 [5] which gives the maximum FRP force which can be anchored and the minimum anchorage length.

The analysis of RC structures members before and after strengthening using CFRP systems are also presented in the fib bulletin 14[5].

A quick overview of the experimental research and analytical studies performed by many authors on the effects of CFRP systems used at RC structures show up some interesting results:

- Test results (Mosallam [6]) on beam-column joints of RC frame structures show an important increase of strength, up to $53 \%$ and ductility up to $42 \%$.

- Parvin and Granata [7] illustrated an increase in the moment capacity up to $37 \%$ given by an analytical analysis (FEM) on exterior beam-column joints.

- The confining pressure of the FRP jackets on bridge columns with a circular cross section shows an increase of the lateral bending strength by $19-40 \%$ (Sclick and Brena [8]).

- The results from an experimental study on a full scale RC structure illustrated an increase by $86-100 \%$ of base shear force and about $100 \%$ increase of lateral topdisplacement capacity by using FRP strengthening (Della Corte, Borecchia and Mazzolani [9]).

\section{Experimental part}

The experimental program focused on RC frames (fig. 1) assumed as existing structures. Single span and single story frame (scale 1:2) was designed and detailed according to the Romanian design codes from 1970 under which seismic design was inadequate: mainly, a lack of reinforcement to withstand the present-day seismic actions.

The materials used were: concrete $\mathrm{C} 16 / 20\left(f_{\mathrm{c}}=16 \mathrm{~N}\right.$ / $\left.\mathrm{mm}^{2} ; f_{c d}=11 \mathrm{~N} / \mathrm{mm}^{2} ; \varepsilon_{c u}=0.0035 ; E_{c}=27 \mathrm{k} \mathrm{k} / \mathrm{mm}^{2}\right) ;$ Romanian plain reinforcement bars OB37 $\left(f_{\mathrm{yk}}=245 \mathrm{~N} /\right.$ $\mathrm{mm}^{2} ; f_{1}=210 \mathrm{~N} / \mathrm{mm}^{2} ; E_{\mathrm{s}}=210 \mathrm{kN} / \mathrm{mm}^{2}$ ).

Finally, due to practical aspects, the manufacture of the experimental models was done as prefabricated frames which were placed in cast on-site foundations.
These frames were loaded vertically with constant forces $\mathrm{P}$ and horizontally with variable alternant forces $\mathrm{S}^{+}$ or $\mathrm{S}$ (seismic action), as presented in figure $2 \mathrm{a}$ and $2 \mathrm{~b}$. During the test were measured: load forces S; strain in reinforcement bars of columns and beams; horizontal and vertical displacements.
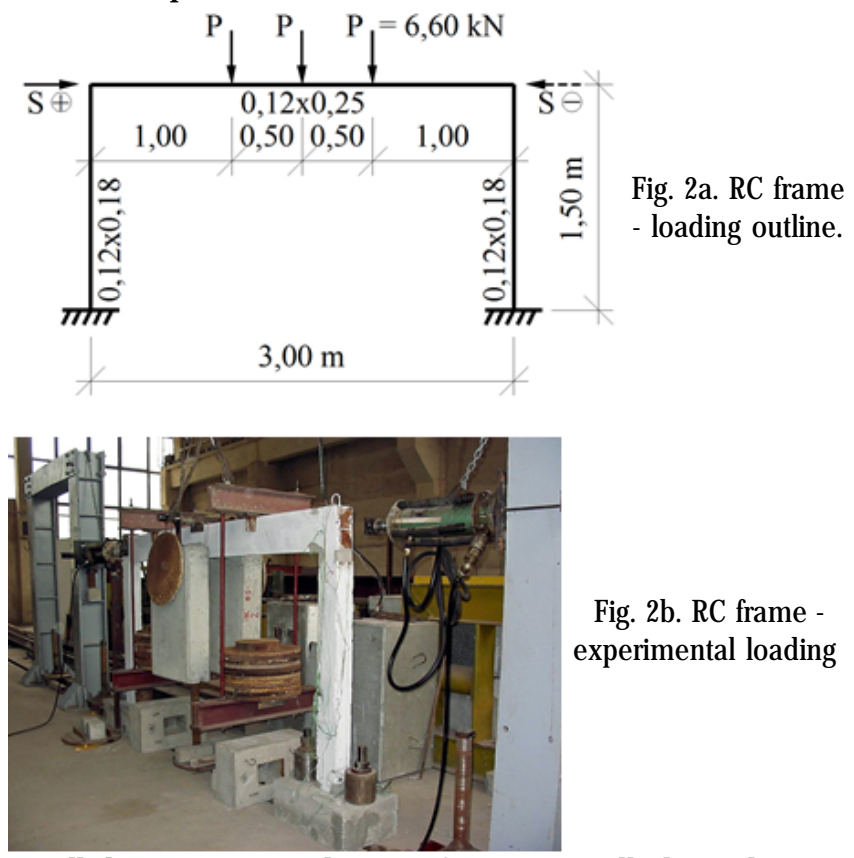

Fig. 2b. RC frame experimental loading

All the tests were done in force controlled conditions, and performed as alternant horizontal cycles, first up to the service stage, and second up to the yielding of reinforcement and failure stage.

The RC structural design, according to the Romanian design codes from 1970, and the magnitude of applied forces were ensuring the failure mechanism, of nonstrengthened RC frames, by plastic hinges at columns ends. It is typical strong beams-week columns failure model.

Then the RC frames were strengthened (fig. 3) on both columns by using CFRP materials:

-longitudinal strips, on two sides, had a width $b_{f}=25$ $\mathrm{mm}$ and a thickness $t=1.2 \mathrm{~mm}$. The strips were anchored in foundations (on $100 \mathrm{~mm}$ depth) and at the top joints in different manners: glued anchorage (fig. 4a); wrap anchorage (fig. 4b); mechanical anchorage (fig. 4c);

-transversal confinement with a single layer of wrap closed jacket at both ends of the columns. The jackets had a width $b_{\mathrm{f}}=300 \mathrm{~mm}$ and a thickness $t=0.12 \mathrm{~mm}$.

CFRP materials characteristics used for strengthening are: $E_{\mathrm{f}}=165 \mathrm{kN} / \mathrm{mm}^{2}$ and $e_{\mathrm{fu}}=0.017$ for longitudinal strips; $E_{i}=231 \mathrm{kN} / \mathrm{mm}^{2}$ and $e_{\mathrm{i}}=0.017$ for transversal wraps. The bond of CFRP materials to the existing concrete layer was assured by specific epoxy adhesives.

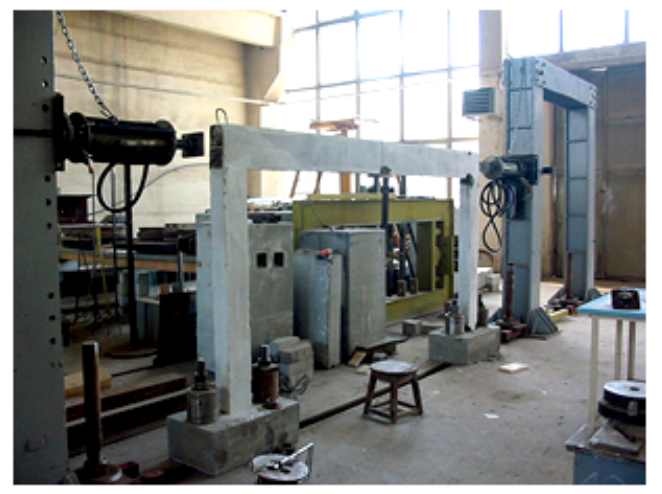

Fig. 1. Reinforced concrete frame model

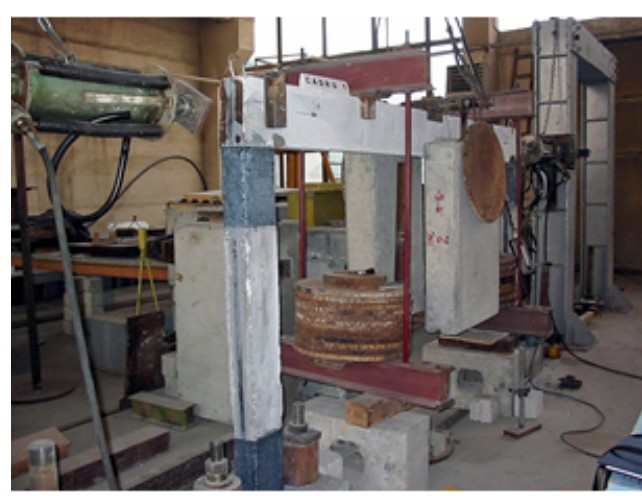

Fig. 3. RC frame + CFRP strengthening. 


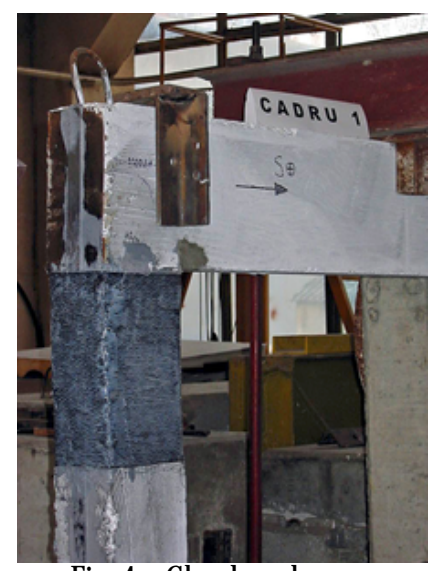

Fig. 4a. Glued anchorage Frame 1

Results and discussions Experimental results

During experimental tests the following parameters were measured: horizontal load S; horizontal displacement at the column-beam node; vertical displacement in the middle of the beam; strain in the longitudinal rebars at the ends of columns and beam; strain in the bottom longitudinal rebars in the middle of the beam.

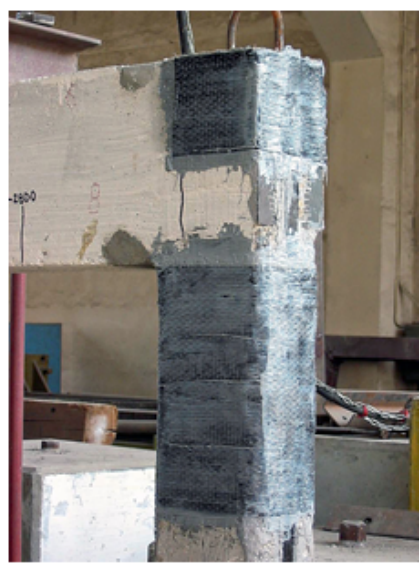

Fig. 4b. Wrap anchorage Frame 2

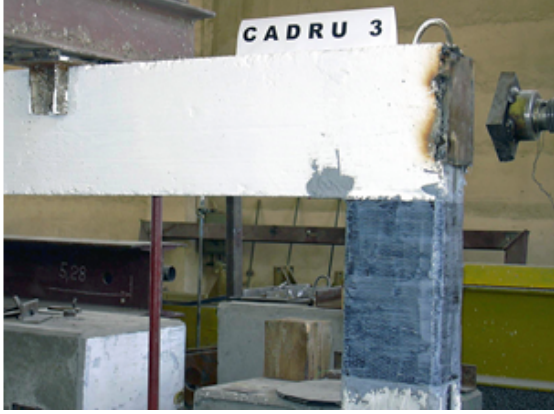

Fig. 4c. Mechanical anchorage Frame 3

From all the experimental data given by tests performed on frame structures the most significant, for the present study, are presented in table 1 and figure 5.

The experimental program emphasized some important aspects regarding the behavior and failure of RC frames strengthened with CFRP:

\begin{tabular}{|c|c|c|c|c|c|}
\hline \multirow[t]{2}{*}{ Model } & \multirow[t]{2}{*}{ State of structure } & \multirow{2}{*}{$\begin{array}{c}\text { Horizontal load S } \\
{[\mathrm{kN}]}\end{array}$} & \multirow{2}{*}{$\begin{array}{l}\text { Top maximum } \\
\text { displacement } \\
\text { [mm] }\end{array}$} & \multicolumn{2}{|c|}{ Ratio $\frac{\text { strengthen ed }}{\text { non - strengthen ed }}$ for } \\
\hline & & & & Loads & Displacements \\
\hline \multirow{4}{*}{ Frame 1} & Non-strengthened & $16^{*}$ & 5.44 & \multirow{4}{*}{-} & \multirow{4}{*}{$\frac{0.71^{*}}{-}$} \\
\hline & \multirow{3}{*}{ CFRP strengthened } & $16^{*}$ & 3.87 & & \\
\hline & & 36 & 14.73 & & \\
\hline & & $40 * \%$ & 30.20 & & \\
\hline \multirow{5}{*}{ Frame 2} & & $16^{*}$ & 4.60 & \multirow{5}{*}{1.06} & \multirow{5}{*}{$\frac{0.98^{*}}{2.00 * *}$} \\
\hline & & $36^{* *}$ & 15.27 & & \\
\hline & \multirow{3}{*}{ CFRP strengthened } & $16^{*}$ & 4.50 & & \\
\hline & & 36 & 15.27 & & \\
\hline & & $38 * \%$ & 30.70 & & \\
\hline \multirow{3}{*}{ Frame 3} & Non-strengthened & $16^{*}$ & 7.60 & \multirow{3}{*}{-} & \multirow{3}{*}{$\frac{0.72^{*}}{-}$} \\
\hline & \multirow{2}{*}{ CFRP strengthened } & $16^{*}$ & 5.50 & & \\
\hline & & $36^{* *}$ & 29.80 & & \\
\hline $\begin{array}{l}* \text { yielc } \\
* \& \text { ultin }\end{array}$ & ef reinforcement; & & & & \\
\hline
\end{tabular}

Table 1 EXPERIMENTAL RESULTS
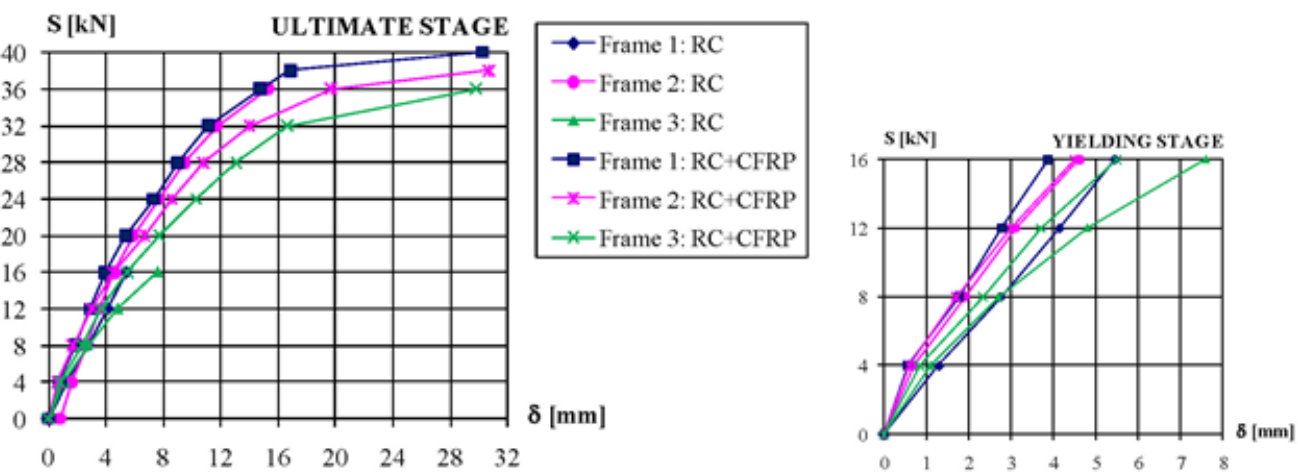

Fig. 5. Top-displacement values for RC non-strengthened and CFRP strengthened frames 


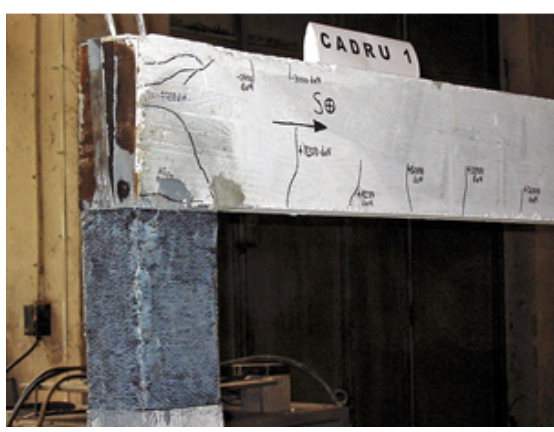

Fig. 6. Debonding of CFRP vertical strip due to tensile stresses

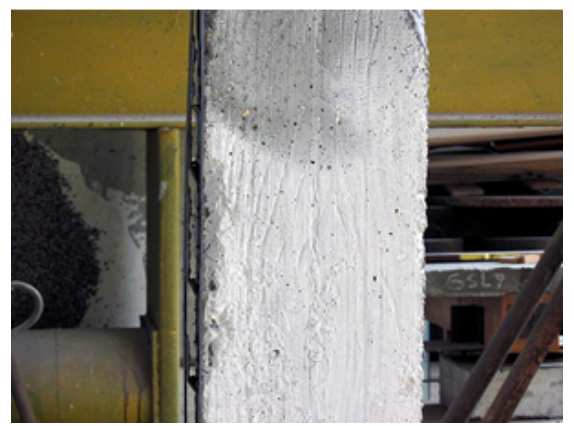

Fig. 7. Debonding of CFRP vertical strip due to compression stresses.

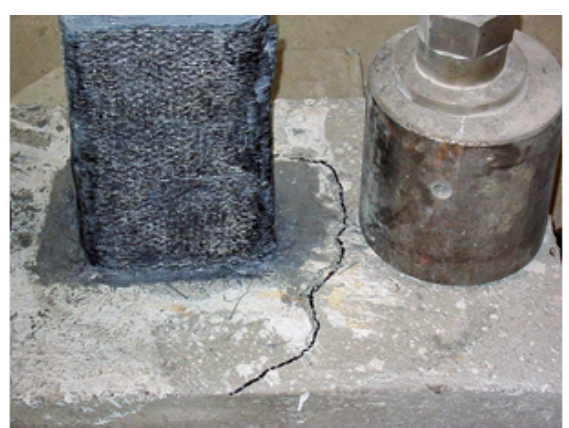

Fig. 8. Pull-out of concrete and CFRP from foundation

Table 2

COMPARISON BETWEEN THEORETICAL AND EXPERIMENTAL VALUES

\begin{tabular}{|c|c|c|c|c|c|c|c|}
\hline \multirow{2}{*}{\multicolumn{2}{|c|}{ State of structure }} & \multicolumn{3}{|c|}{ Resistance capacity $\mathrm{M}_{\mathbb{R d}}[\mathrm{kNm}]$} & \multicolumn{3}{|c|}{ Top-displacement $\delta[\mathrm{mm}]$} \\
\hline & & Theor. & Exp. & Exp./Theor. & Theor. & Exp. & Exp/Theor. \\
\hline \multirow{2}{*}{ Non-strengthened structure } & yielding stage & 7.92 & 8.77 & 1.11 & 4.03 & 5.88 & 1.46 \\
\hline & ultimate stage & 12.90 & 17.06 & 1.32 & 9.07 & 15.27 & 1.68 \\
\hline \multirow{2}{*}{$\begin{array}{l}\text { CFRP strengthened } \\
\text { structure }\end{array}$} & yielding stage & 10.34 & 8.77 & 0.85 & 3.06 & 4.62 & 1.51 \\
\hline & ultimate stage & 13.86 & 17.89 & 1.29 & 7.65 & 21.41 & 2.80 \\
\hline \multirow{2}{*}{$\begin{array}{l}\text { Variation of strength and } \\
\text { stiffness [\%] }\end{array}$} & yielding stage & $31 \%$ & $0 \%$ & - & $32 \%$ & $27 \%$ & - \\
\hline & ultimate stage & $7 \%$ & $5 \%$ & - & $18 \%$ & $-29 \%$ & - \\
\hline
\end{tabular}

-debonding of CFRP vertical strips from glued anchorage (Frame 1) and wrap anchorage (Frame 2) due to tensile stress at the top joints (fig. 6);

-no debonding of CFRP strips from mechanical anchorage (Frame 3 ) at the top joints;

-debonding of CFRP vertical strips on inside face of the column (Frame 2) due to compression (fig. 7) stress which shows the lack of some necessary transversal stirrups to prevent strip buckling;

-a pull-out tendency of ordinary concrete around the polymer mortar used for CFRP fixing into foundations (fig. 8).

\section{Theoretical values}

The theoretical values are based on Eurocode 2: Design of concrete structures -Part 1-1: general rules and rules for buildings [10] for non-strengthened structure and on fib Bulletin 14 Externally bonded FRP reinforcement for $R C$ structures [5] and fib Bulletin 35 Retrofitting of concrete structures by externally bonded FRP [11] for strengthened structure.

The resistance capacity was analyzed for columns subjected to flexure with compression axial force. The resistance capacity expressed by bending moment $M_{\mathrm{Rd}}$ was calculated for yielding stage and for ultimate stage.

For non-strengthened structure, the calculus of $M_{\mathrm{Rd}}$ was done for: rectangular cross-section $120 \times 180^{\mathrm{Rd}} \mathrm{mm}$; symmetric reinforcement $A_{s 1}=A_{s 2}(2 \phi 12 \mathrm{~mm})$; yielding and ultimate strength of steel, since this has been an experimental test.

For strengthened structure, the calculus of $M_{\text {Rd }}$ was done for: reinforced concrete cross-section of the nonstrengthened structure; CFRP strip area $A_{f}=b_{f} \times t_{f}=30$ $\mathrm{mm}^{2}$; yielding and ultimate strength of steel; characteristic and mean compression and tensile strengths of concrete.

The top-displacements were calculated at the same stages, for theoretical and experimental approaches, for non-strengthened RC cross-section as well as for CFRP strengthened cross-section (based on Matthys [5]).

The values of deflections were obtained by using a simplified calculation (CEB-FIP Model Code) [12] which gives reasonable accurate prediction at the service limit state SLS.

A comparison between experimental results of reinforced concrete framed structures and theoretical values are presented in table 2 .

From experimental data and theoretical values presented in table 1 and 2 it can be noticed:

-the values of the maximum horizontal loads were chosen differently for the two non-strengthened frames in order to vary the application level of strengthening: $16 \mathrm{kN}$ (yielding stage of reinforcement) for Frame 1 and 3; $36 \mathrm{kN}$ (ultimate stage) for Frame 2;

-the increase of the experimental bending moment at ultimate stage was only $5 \%$ due to debonding of CFRP strips;

-the experimental values of top-displacements are higher than theoretical data. This fact can be explained by the tangent modulus of concrete $E_{c}$ used instead of secant modulus;

-the increase of stiffness for the strengthened structure implies the smaller value of top-displacement at the yielding stage by $27 \%$ for experimental framed structure (fig. 5) and by $32 \%$ for calculated displacement.

\section{Conclusions}

The experimental tests performed on RC framed structure emphasized some main aspects of the CFRP strengthening system:

-The slight increase of resistance capacity by $5 \%$ at the ultimate stage and the decrease of top-displacement by $27 \%$ at the service stage.

Some results given by other authors, but in different conditions, are presented in table 3, as well as in [13]. 
Table 3

THE EFFECT OF CFRP STRENGTHENING ON RC STRUCTURES

\begin{tabular}{|l|c|c|}
\hline \multirow{2}{*}{ Author(s) } & \multicolumn{2}{|c|}{ The effects [\%] on } \\
\cline { 2 - 3 } & strength & stiffness \\
\hline Mosallam - 2000 & 52 & 42 \\
\hline Parvin and Granata - 2000 & $37^{*}$ & - \\
\hline Sclick and Brena - 2004 & $19-40$ & - \\
\hline Della Corte et all - 2005 & $86-100$ & 100 \\
\hline Nagy-Gyorgy et all - 2004 & $48 / 33^{*}$ & $-(31-69)$ \\
\hline Dan and Bob - 2010 & $5 / 7^{*}$ & $27 / 32^{*}$ \\
\hline \% Theoretical values & & \\
\hline
\end{tabular}

-Peeling-off failure of CFRP strips at the top joint due to debonding without a proper anchorage.

-Debonding of CFRP strips in the compressed zone in case of proper transversal reinforcement absence.

The strengthening solutions based on CFRP systems may be used for rehabilitation of different types of structures, as also shown by Constantin [14] and Lazar [15], due to some important technical and economical advantages: facile strengthening technology and short refurbishment period; resistance to aggressive environments; safe behavior under seismic action; more sustainable solution [16].

Acknowledgements: The present experimental research was supported by the Romanian Ministry of Education and Research MECCNCSIS, Grant No. 32940, 2002-2004, entitled Rehabilitation of Reinforced Concrete Structures by Using Carbon Fiber Reinforced Polymers.

\section{References}

1.BOB, C., Rehabilitation of Existing Structures in Seismic Zones. Progress in Structural Engineering and Materials, Vol. 3, No. 4., 2001; p. 353-359.

2.BOB, C., DAN, S., BADEA, C., IURES, L., Classic and Modern Rehabilitation Techniques in Seismic Zones. IABSE Symposium: Structures and Extreme Events. Lisbon, 2005.
3.EL-AMOURY, J., GHOBARAH, A., Seismic Rehabilitation of BeamColumn J oint Using GFRP Sheets. Engineering Structures (24). 2002; p. 1397-1407.

4.PARESE et al., Seismic Behavior of RC Hollow Section Bridge Piers Retrofitted with FRP. $13^{\text {th }}$ w orld Conference of Earthquake Engineering. Vancouver, Canada, 2004.

5.*** fib Bulletin 14, Externally Bonded FRP Reinforcement for RC Structures. fib, Lausanne, 2001.

6.MOSSALLAM, A., S., Strength and Ductility of RC Moment Frame Connection Strengthened with Quasi-Isotropic Laminates. Composites (31). 2000; p. 481-497.

7.PARVIN, A., GRANATA, G., Investigations on the Effects of Fiber Composite at Concrete Joints. Composites: Part B (31). 2000; p. 499509.

8.SCHLICK, B., M., BRENA, S., F., Seismic Rehabilitation of RC Bridge Column in Moderate Earthquake Regions Using FRP Composites. $13^{\text {th }}$ Conference of Earthquake Engineering. Vancouver, Canada, 2004. 9.DELLA CORTE, G., BORECCHIA, E., MAZZOLANI, F., M., Seismic Upgrading of RC Structures by Means of Composite Materials - a state of the art review. COST C12 Final Conference Proceedings. 2005; $p$. 81-89.

10.*** CEN, Eurocode 2: Design of concrete structures -Part 1-1: general rules and rules for buildings. EN 1992-1-1, CEN, Brussels, 2004.

11.*** fib Bulletin 35, Retrofitting of concrete structures by externally bonded FRPs. fib, Lausanne, 2006.

12.*** CEB, CEB-FIP Model Code 1990, Design Code. Comite EuroInternational du Beton, Lausanne, 1993.

13.CURTU, I., LUCA MOTOC, D., Theoretical - Experimental Comparisons of Multi-phase Composite Materials Elastic Coefficients Retrieved from Tensile, Compressive and Bending Tests. Influencing Factors. Mat. Plast., 45, no. 4, 2008, p. 366-371.

14.CONSTANTIN, A., T., GHITESCU, M.-A., LAZAR, G., NICOARA, S., V., Fish Ladder Numerical Modelling. Rev. Chim. (Bucharest), 69, no. 3, 2018; p. 591-596.

15.LAZAR, G., CONSTANTIN, A., T., GHITESCU, M.-A., NICOARA, S., V., Numerical Modelling of a Town Water Distribution Network -Optimum Location of Quality Sensors. Rev. Chim. (Bucharest), 69, no. 2, 2018; p. 354-364.

16.DAN, S., IURES, L., BADEA, C., Impact of Structural Rehabilitation of Existing Buildings on Energy Saving in Constructions. $13^{\text {th }}$ International Multidisciplinary Scientific GeoConference SGEM: GeoConference on Nano, Bio and Green Technologies for a Sustainable Future. Albena, Bulgaria, 2013; p. 451-456.

Manuscript received:26.07.2018 